Brit. J. vener. Dis. (1962), 38, 64.

\title{
TREATMENT OF NON-GONOCOCCAL URETHRITIS WITH
}

\author{
I.C.I. $17,025 * \dagger$ \\ BY \\ W. A. M. DUNCAN \\ Imperial Chemical Industries Limited, Pharmaceuticals Division, \\ Alderley Park, Macclesfield \\ AND \\ R. S. MORTON \\ The Royal Hospital, West Street, Sheffield
}

Non-gonococcal urethritis (NGU) is an inflammatory condition of the male urethra usually occurring after sexual intercourse. The reported incidence of NGU in England and Wales has doubled since figures were first published a decade ago; in 1960, as estimated from quarterly returns made by V.D. clinics to the Ministry of Health, 21,719 cases were reported.

The aetiology of NGU is unknown. Bacterial activity is generally discounted and the suspected virus or viruses are unidentified. One of the supports of a viral theory has been the prompt response of a high percentage of NGU cases to broad spectrum antibiotics, e.g. the accepted response rate to terramycin is 85 per cent. The broad spectrum antibiotics are not only antibacterial but are antiviral against the larger viruses, and some believe this to be the reason for their success in the treatment of NGU. Any drug therefore with antiviral activity should theoretically be useful in the treatment of NGU. It seemed not unreasonable therefore to treat a series of cases with an antiviral agent having no recognizable antibacterial activity either in vitro or in vivo; such a drug is 17,025 .

The antiviral activity of 17,025 has been described by Hurst and Hull (1961), who showed it to be of very low toxicity in mice, rats, guinea-pigs, and dogs, and to be effective against viruses of the psittacosislymphogranuloma-trachoma group. The compound is non-irritant when administered by the intramuscular route and weight for weight it is rather less than one-tenth as active as chlortetracycline. It was suggested by Hurst and Hull (1961) that its clinical use might perhaps be envisaged when it is desired to

* I.C.I. 17,025 is 5-methoxycarbonyl-6-methyl-4-(5-nitrofuryl) $2-0 \times 0-1,2,3,4$ tetrahydropyrimidine and is the subject of U.K. patent No. 868030 .

† Received for publication January 30, 1962. control an infection by infrequent parenteral therapy, rather than by prolonged topical application or by frequent oral dosing.

The relationship of the clinical results in mice with the concentration of the drug in the blood, the rate of disappearance from the tissues, and the excretion of unchanged drug in the urine have been examined. These results are presented with a study of the concentration of 17,025 in the blood and urine of patients suffering from NGU who were undergoing treatment with the drug. The clinical responses of these patients are discussed.

Clinically 17,025 has been shown to be useful in the treatment of human lymphogranuloma inguinale (Alergant, 1961).

\section{Material}

Race.-A total of 33 cases was studied; thirteen were coloured, twenty white.

Age.-The average age was $29 \cdot 6$ years (range 21 to 43 ).

Marital Status.-Twenty were married or married and separated; thirteen were single or widowed.

Past Venereal History. - Fifteen patients had no past history of venereal disease or past genito-urinary infection; the remaining eighteen had shared fourteen attacks of gonorrhoea, eight attacks of NGU, and two attacks of syphilis.

Source of Infection.-This was marital in four cases, extra-marital in twenty, and doubtful in nine.

Incubation Period.-This was judged to be 9 days or less in fifteen, 10 days or over in ten, and doubtful in eight.

Duration of Urethral Discharge.-This was 9 days or less in 27 cases and 10 days or more in six.

\section{Case Management}

In every case, before treatment, direct specimens were examined for gonococci and Trichomonas vaginalis; specimens were also cultured for these organisms. Serological tests for syphilis were made routinely. In no case 
was the gonococcus observed in Gram-stained urethral smears or in cultures. In four cases Trichomonas vaginalis cultures were found to be positive after treatment with 17,025 had been started. There was no case of positive syphilis serology.

17,025 was supplied for deep intramuscular injection in the upper and outer quadrant of the buttock as $2 \mathrm{~g}$. doses in $8 \mathrm{ml}$. arachis oil. In some cases two doses were given with a 7-day interval, and in the others three injections were spaced over 7 days, injections being given on days 1,3 , and 7 .

All patients were dealt with on an out-patient basis. The urine was examined and a Gram-stained smear of any urethral discharge made at each attendance. In cases in which the patient could attend at the required times, specimens of blood and urine were obtained for drug analysis. A follow-up of 3 months from completion of treatment was aimed at in all cases.

\section{Methods}

Estimation of 17,025 in Blood and Urine.-The blood, which was oxalated, and the urine samples were stored in light-tight glass containers at about $4^{\circ} \mathrm{C}$. until required for analysis. Care was exercised to limit the amount of light which reached samples containing the drug at any point during the estimation, as compound 17,025 is photolabile, especially in dilute solution, as was shown by a decrease in optical density at $310 \mathrm{~m} \mu$ on exposure to light. Chloroform ( $30 \mathrm{ml}$. A.R. quality), which was purified by successive washings with $1 . \mathrm{ON} \mathrm{NaOH}, 1 . \mathrm{ONHCl}$ and three washings with water, was added to the blood or urine sample $(5 \mathrm{ml}$.) and the drug was extracted into the chloroform by shaking for 5 minutes. A portion $(25 \mathrm{ml}$.) of the chloroform extract was transferred to a test tube and evaporated to dryness at $40^{\circ} \mathrm{C}$.; the rate of evaporation was increased by directing a jet of air on to the surface of the extract. Methanol ( $2 \mathrm{ml}$. A.R. quality) was added to the residue to dissolve the drug, and the solution was filtered directly into $40-\mathrm{mm}$. silica micro-cuvettes. The optical density of the extract was measured at $270 \mathrm{~m} \mu$ and $310 \mathrm{~m} \mu$ in an Unicam S.P. 500 ultra-violet spectrophotometer fitted with the Unicam S.P. 580 microcell attachment. All the measurements were made with the disk adjacent to the exit slit of the monochromator set at $4 \times 12 \mathrm{~mm}$.

The chloroform extracted substances from the blood and urine which absorbed ultra-violet light at $270 \mathrm{~m} \mu$ and $310 \mathrm{~m} \mu$, so that to determine the concentration of 17,025 in a chloroform extract it was necessary to make allowance for this background absorption. The concentration of 17,025 in the blood and urine was calculated as follows:

$B$ is the ratio of the optical density at $270 \mathrm{~m} \mu$ to the optical density at $310 \mathrm{~m} \mu$ for blood or urine before dosage with the drug.

$d_{1}$ and $d_{2}$ are the optical densities of the test sample at $270 \mathrm{~m} \mu$ and $310 \mathrm{~m} \mu$ respectively.

Then

$\mu g .17,025 / 10 \mathrm{ml}$. blood or urine $=27 \cdot 5 \frac{d_{2} B-d_{1}}{B-1 \cdot 0}$.
This formula applies only when the value for $B$ is greater than 1.0 as was always found. With animals the value of $B$ was fairly constant at about $3 \cdot 4$, whilst with patients the blood gave a value of $3.35 \pm 1.00$ and the urine a value of $4.32 \pm 2.05$ before treatment.

Studies on Mice.-Groups of five to ten mice (each about $20 \mathrm{~g}$.) were injected intramuscularly with $0.1 \mathrm{ml}$. of either $10,5,2$, or 1 per cent. suspension of 17,025 in arachis oil, and the concentration of 17,025 in the blood and tissues was determined at varying intervals after injection. The drug in the tissues was measured by homogenizing the carcase in water and then estimating the drug using the method described for blood and urine.

\section{Results}

After intramuscular injection the rate of disappearance of 17,025 from the tissues of mice appeared to be independent of the dose (Table I).

\section{TABLE I}

AMOUNT OF 17,025 (mg.) REMAINING IN THE MOUSE CARCASE AFTER INTRAMUSCULAR INJECTION OF VAR YING DOSES OF THE COMPOUND

\begin{tabular}{|c|c|c|c|c|c|}
\hline \multirow{2}{*}{$\begin{array}{c}17,025 \\
\text { (mg. per } \\
20 \text { g. mouse) }\end{array}$} & \multicolumn{5}{|c|}{ Days after Injection } \\
\hline & 1 & 2 & 3 & 4 & 7 \\
\hline 10 & $4 \cdot 5$ & $3 \cdot 1$ & $2 \cdot 8$ & $1 \cdot 6$ & 0.7 \\
\hline 5 & $2 \cdot 1$ & $1 \cdot 7$ & 0.5 & 0.4 & 0.4 \\
\hline 2 & $1 \cdot 2$ & $0 \cdot 4$ & 一 & - & 一 \\
\hline 1 & 0.4 & - & - & - & - \\
\hline
\end{tabular}

Over 50 per cent. of the administered dose could not be accounted for in the tissues 24 hours after injection. Although this loss from the tissues was partially accounted for by urinary excretion (Table II), the small amounts of 17,025 recovered in the urine (2-6 per cent. of the administered dose) indicated that the drug was being metabolized.

\section{TABLE II}

EXCRETION OF 17,025 (mg.) IN THE URINE OF GROUPS OF TWENTY MICE AFTER INTRAMUSCULAR INJECTION OF VARYING DOSES OF THE COMPOUND

\begin{tabular}{c|c|c|c|c|c}
\hline \multirow{2}{*}{$\begin{array}{c}\text { 17,025 } \\
\text { (mg. per } \\
20 \text { g. mouse) }\end{array}$} & \multicolumn{5}{|c}{ Hours after Injection } \\
\cline { 2 - 6 } & $0-24$ & $24-48$ & $48-72$ & $72-96$ & $168-192$ \\
\hline 10 & 1.93 & 2.19 & 0.92 & 0.94 & 0.15 \\
\hline 5 & 2.45 & 1.82 & 0.82 & 0.47 & 0 \\
\hline 2 & 0.49 & 0.09 & 0.02 & 0 & - \\
\hline 1 & 2.25 & 0.49 & 0.09 & 0 & - \\
\hline
\end{tabular}


Table III presents the concentration of 17,025 in the blood of mice at varying intervals after injection; 24 hours later the concentration remaining in the blood was 40 per cent. or less of the maximum concentration attained.

TABLE III

CONCENTRATION OF $17,025(\mu \mathrm{g} . / \mathrm{ml}$.) IN THE BLOOD OF MICE AFTER INTRAMUSCULAR INJECTION OF VARYING DOSES OF THE COMPOUND

\begin{tabular}{|c|c|c|c|c|c|}
\hline \multirow{2}{*}{$\begin{array}{c}17,025 \\
(\mathrm{mg} . \text { per } \\
20 \mathrm{~g} . \text { mouse })\end{array}$} & \multicolumn{5}{|c|}{ Hours after Injection } \\
\hline & 2 & 4 & 7 & 24 & 72 \\
\hline 10 & $2 \cdot 4$ & $2 \cdot 7$ & $2 \cdot 3$ & $1 \cdot 0$ & $0 \cdot 7$ \\
\hline 5 & $1 \cdot 8$ & $1 \cdot 8$ & $2 \cdot 2$ & $0 \cdot 7$ & 0.3 \\
\hline 2 & $1 \cdot 8$ & $1 \cdot 9$ & $1 \cdot 3$ & 0.4 & $0 \cdot 1$ \\
\hline 1 & $1 \cdot 8$ & $1 \cdot 6$ & 0.7 & 0.1 & - \\
\hline
\end{tabular}

The maximum concentrations were not markedly affected by dose, but a straight line relationship was shown to exist between the logarithm of the dose and the area below the "blood level" curve for the 72 hours after injection (Figure).

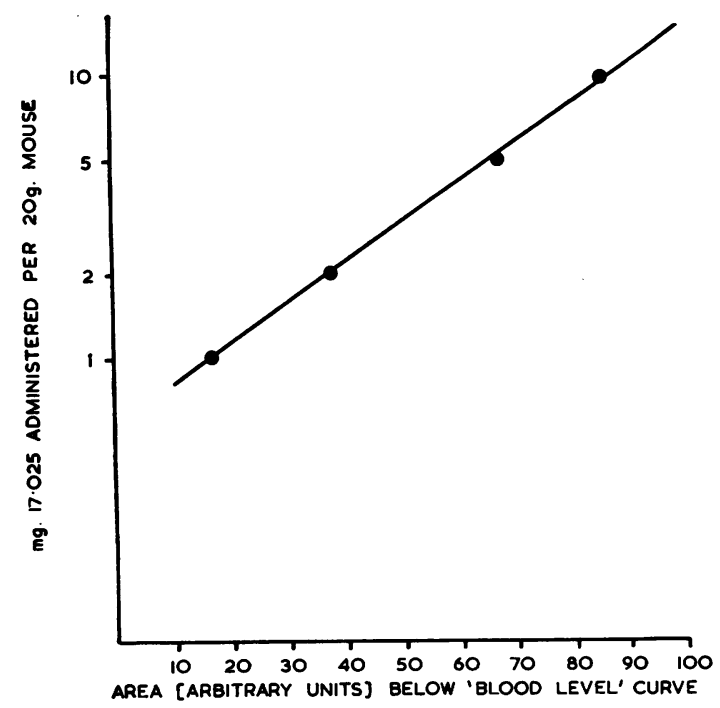

FiguRE.-Effect of varying intramuscular doses of 17,025 on the amount of drug found in the blood in mice during the 72 hours after injection.

The concentrations of 17,025 in the blood and urine of patients receiving the drug by one of two dosing schedules were extremely variable (Tables IV and V, opposite), but the results indicated that 17,025 was more persistent in man than it was in mice. Although the urine samples analysed were overnight mid-stream specimens, there was little doubt that as in mice only a small percentage of the administered dose was excreted unchanged.

In four cases Trichomonas vaginalis positive cultures excluded the patients concerned from the trial. Six patients defaulted during or so soon after completion of treatment that no adequate follow-up was possible. These have been excluded from the study.

Of the 23 remaining, fourteen received two injections of 17,025 at a 7-day interval and nine received three injections on days 1,3 , and 7 . There was little difference in the response rate of these two groups and therefore all 23 cases are considered together. A total of twelve failed to respond. The remaining eleven were all judged to be "cured"* and were seen at least twice during the first week after completion of treatment. Ten were followed for 2 weeks or more, seven for a month or more, and three for 3 months. Recurrences occurred in two cases; in one 2 weeks and in the other 10 weeks after completion of treatment.

The 33 men originally taking part in this study received a total of 73 injections of 17,025 . There was local induration of both buttocks in two patients, and one buttock was affected in three patients. Four others complained of some tenderness at the site of injection. Of the total of nine men complaining, eight also complained of cramps in the thigh and leg muscles.

\section{Discussion}

The analytical method which was used will detect $0.5 \mu \mathrm{g} .17,025$ per $10 \mathrm{ml}$. blood or urine. The technique apparently only detected 17,025 , as the material extracted from the blood and tissues of injected mice had a similar ultra-violet absorption spectrum and chromatographic mobility to 17,025 . In the mouse and in man a high percentage of the administered dose was metabolized, as not more than 10 per cent. could be detected in the urine; faecal excretion was not examined but this appears an unlikely factor.

Variation of the dose administered to mice had little effect on the peak concentration of the drug in the blood, so that the antiviral effect of a particular dose (Table VI, overleaf) in mice would appear to be a function of the persistence of detectable concentrations in the blood. The concentrations of 17,025 found in the blood in man following an initial intramuscular injection of $2 \mathrm{~g}$. were low and variable, although the compound was obviously being absorbed as it was detected in all urine samples examined. Although the drug was still being excreted

\footnotetext{
* "Cured" here means absence of urethral discharge and a clear
urine.
} 
TABLE IV

CONCENTRATIONS OF 17, $025(\mu \mathrm{g} . / 10 \mathrm{ml}$.) IN BLOOD AND URINE OF PATIENTS AFTER AN INTRAMUSCULAR INJECTION OF 2 g. 17, 025, FOLLOWED AFTER 7 DAYS BY A SECOND INJECTION OF 2 g.

\begin{tabular}{|c|c|c|c|c|c|c|c|c|c|c|c|c|c|c|c|c|c|c|c|c|}
\hline \multirow{2}{*}{$\begin{array}{c}\text { Days } \\
\text { after } \\
\text { First } \\
\text { Injec- } \\
\text { tion }\end{array}$} & \multicolumn{2}{|c|}{16120} & \multicolumn{2}{|c|}{16140} & \multicolumn{2}{|c|}{16156} & \multicolumn{2}{|c|}{16158} & \multicolumn{2}{|c|}{16202} & \multicolumn{2}{|c|}{16224} & \multicolumn{2}{|c|}{16234} & \multicolumn{2}{|c|}{16284} & \multicolumn{2}{|c|}{16304} & \multicolumn{2}{|c|}{16334} \\
\hline & Blood & Urine & Blood & Urine & Blood & Urine & Blood & Urine & Blood & Urine & Blood & Urine & Blood & Urine & Blood & Urine & Blood & Urine & Blood & Urine \\
\hline 1 & 6.0 & $7 \cdot 5$ & $15 \cdot 0$ & $\overline{11 \cdot 5}$ & 0 & $6 \cdot 0$ & $2 \cdot 5$ & $11 \cdot 0$ & $7 \cdot 0$ & $34 \cdot 0$ & $2 \cdot 5$ & $\overline{30.0}$ & $3 \cdot 0$ & $14 \cdot 0$ & 0 & 0 & $11 \cdot 0$ & $8 \cdot 0$ & 0 & $9 \cdot 0$ \\
\hline 3 & - & - & 0.5 & $\overline{11 \cdot 0}$ & 0 & $10 \cdot 0$ & 0 & $14 \cdot 5$ & $1 \cdot 0$ & 0 & 0.5 & $\overline{16.0}$ & - & - & 0 & 0 & $5 \cdot 0$ & 9.0 & - & - \\
\hline 4 & - & - & - & - & - & - & - & - & - & - & - & - & 0 & $9 \cdot 0$ & - & - & - & - & - & - \\
\hline 5 & - & - & $1 \cdot 0$ & 10.0 & 0 & $7 \cdot 5$ & 0 & $6 \cdot 5$ & $2 \cdot 5$ & $17 \cdot 5$ & 0 & $13 \cdot 0$ & - & - & 0 & $2 \cdot 0$ & 0 & $4 \cdot 5$ & $6 \cdot 5$ & $30 \cdot 0$ \\
\hline 6 & 0 & $6 \cdot 5$ & - & - & - & - & - & - & - & - & - & - & - & - & - & - & - & 一 & - & - \\
\hline 7 & 0 & $5 \cdot 0$ & $13 \cdot 0$ & $7 \cdot 5$ & $1 \cdot 5$ & $13 \cdot 5$ & 0 & $2 \cdot 0$ & $4 \cdot 0$ & $14 \cdot 5$ & 0 & 0 & 0 & 0 & 0 & 0 & $7 \cdot 0$ & 9.0 & $9 \cdot 0$ & $31 \cdot 5$ \\
\hline 8 & - & - & $5 \cdot 0$ & $\overline{28 \cdot 5}$ & $25 \cdot 0$ & $\overline{25 \cdot 5}$ & - & - & $3 \cdot 0$ & 30.0 & - & - & $5 \cdot 0$ & $24 \cdot 0$ & - & - & $5 \cdot 5$ & $\overline{34 \cdot 5}$ & $13 \cdot 0$ & $8 \cdot 5$ \\
\hline 10 & 0 & $2 \cdot 0$ & $2 \cdot 0$ & $11 \cdot 5$ & $7 \cdot 5$ & $24 \cdot 5$ & - & - & $6 \cdot 5$ & $23 \cdot 0$ & - & - & - & - & - & - & $5 \cdot 0$ & $13 \cdot 5$ & $5 \cdot 5$ & $37 \cdot 5$ \\
\hline 11 & - & - & - & - & - & - & - & - & - & - & - & - & - & $44 \cdot 0$ & - & - & 0 & $27 \cdot 0$ & - & - \\
\hline 12 & $1 \cdot 5$ & 0 & $29 \cdot 0$ & $7 \cdot 5$ & $5 \cdot 0$ & $19 \cdot 0$ & - & - & 0 & $19 \cdot 0$ & 一 & - & - & - & - & - & - & - & $8 \cdot 0$ & $52 \cdot 0$ \\
\hline 13 & - & - & - & - & - & - & - & - & - & - & - & - & 0 & 108 & - & - & - & - & - & - \\
\hline 14 & - & - & $6 \cdot 5$ & $\overline{5 \cdot 5}$ & 6.0 & $\overline{18 \cdot 5}$ & - & - & 0 & $6 \cdot 5$ & - & - & - & - & - & - & $4 \cdot 0$ & $8 \cdot 5$ & 8.0 & $23 \cdot 5$ \\
\hline
\end{tabular}

TABLE V

CONCENTRATIONS OF 17, 025 ( $\mu \mathrm{g}$./10 ml.) IN BLOOD AND URINE OF PATIENTS AFTER AN INTRAMUSCULAR INJECTION OF 2 g. 17, 025, FOLLOWED BY FURTHER INJECTIONS OF 2 g. ON THE THIRD AND SEVENTH DAYS

\begin{tabular}{|c|c|c|c|c|c|c|c|c|c|c|c|c|c|c|c|c|c|c|c|c|}
\hline \multirow{2}{*}{$\begin{array}{c}\text { Days } \\
\text { after } \\
\text { First } \\
\text { Injec- } \\
\text { tion }\end{array}$} & \multicolumn{2}{|c|}{16358} & \multicolumn{2}{|c|}{16378} & \multicolumn{2}{|c|}{$16 / 168$} & \multicolumn{2}{|c|}{16388} & \multicolumn{2}{|c|}{16426} & \multicolumn{2}{|c|}{16368} & \multicolumn{2}{|c|}{16466} & \multicolumn{2}{|c|}{16496} & \multicolumn{2}{|c|}{16514} & \multicolumn{2}{|c|}{16518} \\
\hline & Blood & Urine & Blood & Urine & Blood & Urine & Blood & Urine & Blood & Urine & Blood & Urine & Blood & Urine & Blood & Urine & Blood & Urine & Blood & Urine \\
\hline 1 & 0.3 & $\overline{23 \cdot 5}$ & J & $\overline{16 \cdot 0}$ & $7 \cdot 0$ & $39 \cdot 0$ & 5 & $\overline{5 \cdot 5}$ & 0 & 0 & 4.0 & $25 \cdot 0$ & - & - & 1.5 & 0 & 0.5 & 2.0 & 0 & $2 \cdot 0$ \\
\hline 3 & $10 \cdot 5$ & $29 \cdot 0$ & $11 \cdot 5$ & 15.0 & 0 & $27 \cdot 5$ & 13.0 & $41 \cdot 0$ & 0.5 & $16 \cdot 0$ & $6 \cdot 5$ & $10 \cdot 5$ & - & - & 0 & $7 \cdot 0$ & $6 \cdot 5$ & $41 \cdot 5$ & $3 \cdot 5$ & $3 \cdot 0$ \\
\hline 4 & .0 & .5 & .5 & $33 \cdot 5$ & $2 \cdot 5$ & 50.5 & $13 \cdot 0$ & $1 \cdot 0$ & 0 & $1 \cdot 0$ & $11 \cdot 5$ & $1 \cdot 5$ & 0 & $2 \cdot 0$ & 0 & $1 \cdot 0$ & $1 \cdot 5$ & 0.5 & $3 \cdot 0$ & 0.0 \\
\hline 5 & - & - & - & - & - & - & - & - & - & - & - & - & 0 & $23 \cdot 0$ & - & - & - & - & - & - \\
\hline 6 & $9 \cdot 5$ & $7 \cdot 0$ & $9 \cdot 5$ & $19 \cdot 5$ & - & - & 6.0 & 43.0 & $2 \cdot 0$ & 5.0 & $9 \cdot 5$ & 8.0 & - & - & 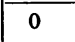 & $25 \cdot 0$ & $7 \cdot 5$ & $56 \cdot 5$ & 6.0 & $25 \cdot 0$ \\
\hline 7 & - & - & - & - & - & - & - & - & - & - & - & - & 0 & $21 \cdot 5$ & - & - & - & - & - & - \\
\hline 8 & $2 \cdot 5$ & $17 \cdot 5$ & $16 \cdot 5$ & $18 \cdot 5$ & $6 \cdot 5$ & - & $21 \cdot 5$ & $10 \cdot 5$ & $30 \cdot 0$ & 0 & 0 & - & - & - & . & - & $2 \cdot 0$ & $25 \cdot 0$ & & - \\
\hline 9 & - & - & - & - & - & - & - & - & - & - & - & - & $4 \cdot 0$ & $7 \cdot 5$ & - & - & - & - & - & 一 \\
\hline 10 & $2 \cdot 5$ & 9.0 & $10 \cdot 5$ & $14 \cdot 5$ & $3 \cdot 5$ & $18 \cdot 5$ & $11 \cdot 0$ & $24 \cdot 5$ & - & 0 & $3 \cdot 5$ & $11 \cdot 0$ & - & - & - & - & $10 \cdot 0$ & $31 \cdot 5$ & 0 & 18.0 \\
\hline 11 & $3 \cdot 0$ & $9 \cdot 0$ & $9 \cdot 5$ & $28 \cdot 5$ & $8 \cdot 0$ & $35 \cdot 0$ & $8 \cdot 0$ & $45 \cdot 5$ & 0 & $5 \cdot 0$ & $4 \cdot 0$ & $21 \cdot 0$ & 0 & $5 \cdot 0$ & - & - & $15 \cdot 0$ & $8 \cdot 5$ & 8.0 & $3 \cdot 0$ \\
\hline 12 & - & - & - & - & - & - & - & - & - & - & - & - & $9 \cdot 5$ & $16 \cdot 0$ & - & - & - & - & - & - \\
\hline 13 & $3 \cdot 5$ & $8 \cdot 0$ & $5 \cdot 5$ & $24 \cdot 5$ & - & - & $8 \cdot 5$ & $32 \cdot 0$ & $4 \cdot 0$ & $9 \cdot 0$ & $2 \cdot 5$ & $6 \cdot 3$ & - & - & - & - & $3 \cdot 0$ & $22 \cdot 0$ & 0 & $22 \cdot 5$ \\
\hline 14 & 0 & $6 \cdot 0$ & - & - & $1 \cdot 0$ & $2 \cdot 6$ & - & - & - & - & - & - & $3 \cdot 5$ & $20 \cdot 5$ & - & - & - & - & - & - \\
\hline 15 & - & - & $9 \cdot 0$ & $11 \cdot 5$ & - & - & $10 \cdot 5$ & $8 \cdot 5$ & 0 & $5 \cdot 5$ & $5 \cdot 0$ & 8.0 & - & - & - & - & $8 \cdot 5$ & $22 \cdot 0$ & $2 \cdot 5$ & $\overline{16 \cdot 5}$ \\
\hline 16 & - & - & - & - & $2 \cdot 0$ & $6 \cdot 0$ & - & - & - & - & - & - & $8 \cdot 0$ & $8 \cdot 5$ & - & - & - & - & - & - \\
\hline 17 & - & - & $9 \cdot 5$ & $5 \cdot \overline{5}$ & - & - & 0 & $43 \cdot \overline{0}$ & 0 & $8 \cdot \overline{0}$ & $4 \cdot 0$ & $8 \cdot \overline{5}$ & - & - & - & - & 0 & $26 \cdot 5$ & - & - \\
\hline 18 & 0 & .5 & - & -7 & $7 \cdot 5$ & $24 \cdot \overline{5}$ & - & - & - & - & - & - & - & - & - & - & - & - & - & - \\
\hline
\end{tabular}


TABLE VI

EFFECT OF VARIOUS INTRAMUSCULAR DOSES OF 17,025 ON INFECTIONS IN THE MOUSE WITH L.G.V. VIRUS

\begin{tabular}{c|l}
\hline $\begin{array}{c}17,025 \\
\text { (mg. per } \\
20 \text { g. mouse) }\end{array}$ & Results \\
\hline 10 & Complete control of infection. \\
\hline 5 & Slight symptoms with 4/10 late deaths. \\
\hline 2 & $\begin{array}{l}\text { More marked symptoms with 6/10 delayed } \\
\text { deaths. }\end{array}$ \\
\hline 1 & $\begin{array}{l}\text { Symptoms less marked than in controls (7th } \\
\text { day). 5/10 deaths in 7-9 days. }\end{array}$ \\
\hline Controls & Marked symptoms with 12/20 deaths in 7-8 days. \\
\hline
\end{tabular}

in the urine 5 to 7 days after this injection, the concentrations of 17,025 in the majority of blood samples taken at this time were below the limit of detection. There appeared to be a better clinical response in the patients in whom 17,025 was more persistent, although the numbers were small. In the second group of patients, therefore, the initial injection was followed after 3 days and then after another 4 days by further injections of $2 \mathrm{~g}$. With this dosage schedule it was hoped that the slightly higher concentrations found in the blood would be sufficient to give a better clinical response. This hope was unfulfilled and there was apparently no relationship between blood concentration or urinary excretion and clinical response.

\section{Summary and Conclusions}

I.C.I. 17,025, a drug of proven antiviral activity and without detectable antibacterial activity, has been given a clinical trial in NGU, a condition of unproven viral origin. The drug, in the dosages used, proved to be of little value in the treatment of NGU. In mice the concentrations of 17,025 in the blood and the rate of disappearance of the drug from the tissues were correlated with the antiviral activity of the compound.

The authors wish to thank Dr. E. Weston Hurst for the results shown in Table VI.

\section{REFERENCES}

Alergant, C. D. (1961). Brit. J. vener. Dis., 37, 270.

Hurst, E. Weston, and Hull, R. (1961). J. med. pharm. Chem., 3, 215.

Traitement de l'urétrite non-gonococcique par l'I.C.I. 17,025

\section{RÉSUMÉ}

L'I.C.I. 17.025, un virulicide bien attesté et nonbactéricide, a été soumis à l'épreuve contre l'urétrite non-gonococcique, maladie dont l'étiologie est inconnue. Ce médicament n'est pas du tout éfficace contre cette maladie.

Les concentrations de 17.025 dans le sang et la vitesse de sa disparition des tissus du corps chez la souris sont corrélatives avec son activité virulicide. 